\title{
Menedzsment módszerek az Ipar 4.0 tükrében
}

\section{R. FILEP}

Debreceni Egyetem Gazdaságtudományi Kar, Ihrig Károly Gazdálkodás- és Szervezéstudományok Doktori Iskola, filep.roland@econ.unideb.hu

Absztrakt. A negyedik ipari forradalom a technológiai szempontok mellett menedzsment oldalról nézve is komoly kihívások elé állítja a szervezeteket. A megfelelő irányítás létfontosságú, segíthet leküzdeni a képzett munkaerőhiány és a költségcsökkentési nyomás támasztotta nehézségeket, valamint javítani az erőforráshatékonyságot. Az újítások megvalósításához olyan menedzsment módszerek szükségesek, amelyek támogatják az ipar 4.0-nak a bevezetését. Szakirodalmi feldolgozásommal arra keresem a választ, hogy ennek az új területnek a jelenlegi kidolgozottsági foka milyen segítséget tud nyújtani a KKV-k vezetői számára ahhoz, hogy a szervezet jobban tudja fogadni a változásokat. Az áttekintett irodalmak alapján menedzsment oldalról nézve a szervezeti struktúra, a vezetési stílus és a HR gyakorlatok kulcsfontosságúak a tanuláshoz és az innovációhoz megfelelő légkör kialakításában. Struktúra vonatkozásában a kutatók nem tesznek javaslatot egyetlen feltétlenül alkalmazandóra, viszont hangsúlyozzák, hogy az ipar 4.0-t instabil, változó környezet jellemzi, ezért olyan struktúrát érdemes kialakítani, amelyet decentralizáció, kevés szabály, horizontális kommunikáció és együttműködő csapatmunka jellemez, azaz sokkal inkább organikus, mint mechanikus. Vezetési stílus tekintetében a transzformációs vezetés kerül említésre a leggyakrabban, viszont az ipar 4.0 esetében ennél is többre van szükség, mert különböző korlátai lehetnek. A szakirodalom az ipar 4.0 elött is kiemelte, hogy a transzformációs és a tranzakciós vezetés megfelelő kombinációjaként határozható meg az ajánlott vezetési stílus, az utóbbi évek ipar 4.0-val kapcsolatos kutatásai is azt hangsúlyozzák, hogy a kettő elegyeként előálló tudás orientált vezetési stílus kibővített konstrukciója könnyítheti meg leginkább az innovációt és a tanulást. A vezetők különféle HR gyakorlatokkal alakíthatják a dolgozók készségeit, javíthatják tanulási képességeiket. A megfelelő struktúra, a vezetési stílus és a HR tehát felkészítik a szervezetet az ipar 4.0-re azáltal, hogy megkönnyítik a tanulást, javítják a képességeket és az innovációt.

Abstract. The fourth industrial revolution poses major challenges for organisations in terms of technological aspects and from a management point of view, too. Good (effective) management is vital as it can help overcome the difficulties arising from shortages of skilled labour and from cost-cutting pressures, and it can help improve efficiency of resources. Innovations require management methods that support the introduction of industry 4.0. In my review of the literature, I aim to find out how the current level of sophistication in this new field can help managers of SME to better embrace change. Based on the reviewed literature, from management point of view, organisational structure, leadership style and HR practices are key to creating an atmosphere conducive to learning and innovation. In terms of structure, researchers do not suggest one thing to apply, but emphasise that industry 4.0 is characterised by an unstable, changing environment, so it is worth developing a structure that is characterised by decentralisation, few rules, horizontal communication and collaborative teamwork, i.e. much more organic than mechanical. In terms of different leadership styles, it is the transformational leadership that is the most often mentioned, however, in case of industry 4.0, we need even more because it can have various limitations. Even before industry 4.0, literature has highlighted that the recommended leadership style can be defined as the combination of transformational and transactional leadership; research in industry 4.0 in recent years also emphasises that it is the expanded construction of a knowledge-driven leadership style that blends the two, which can best facilitate innovation and learning. Managers can develop employee skills and improve their learning abilities through a variety of HR practices. 
So the right structure, leadership style and HR prepare the organisation for industry 4.0 by facilitating learning, improving skills and innovation.

\section{Bevezetés}

A 2008-as gazdasági válság nehézségei, majd a negyedik ipari forradalom újításai a technológiai kihívások mellett menedzsment oldalról nézve is nagy feladat elé állították a szervezeteket. A vezetők számára komoly próbatételt jelent a turbulens környezethez való alkalmazkodás. Szinte minden iparágban munkaerőhiány alakult ki (Sebők, 2017), a fokozódó verseny miatt a szervezeteknek ügyelni kell a költségekre és a szűkösen rendelkezésre álló erőforrásokra, hogy meg tudják állni a helyüket a piacon. A reformok megvalósításához olyan menedzsment módszerek szükségesek, amelyek támogatják az ipar 4.0-nak a bevezetését. A megfelelő irányítás létfontosságú, segíthet leküzdeni a képzett munkaerőhiány és a költségcsökkentési nyomás támasztotta nehézségeket, valamint javítani az erőforrás-hatékonyságot (Horváth és Szabó, 2017).

Szakirodalmi feldolgozásommal arra keresem a választ, hogy az ipar 4.0-nak, mint új területnek a jelenlegi kidolgozottsági foka milyen támogatást tud nyújtani a KKV-k vezetői számára ahhoz, hogy a szervezet jobban tudja fogadni a változásokat. Milyen menedzsment módszerek segíthetnek a tanulást és az innovációt támogató légkör kialakításában.

A következő fejezetben áttekintem a szakirodalomban szereplő menedzsment módszereket, majd bemutatom az eredményeket, végül levonom a konzekvenciát a leírtakból.

\section{Menedzsment módszerek}

A Bevezetés fejezetben írt célkitűzéseim mentén áttekintett irodalmak alapján menedzsment oldalról nézve a szervezeti struktúra, a vezetési stílus és a HR gyakorlatok kulcsfontosságúak a tanuláshoz és az innovációhoz megfelelő légkör kialakításában (Horváth és Szabó, 2017; Shamim et al., 2016; Van Der Sluis, 2004). Az alábbiakban a felsorolás sorrendjében mutatom be ezeket, az értékelésüket pedig az eredmények fejezet tartalmazza.

\subsection{Szervezeti struktúra}

A megfelelő struktúra kulcsszerepet játszhat egy szervezet életében az adaptív környezet megteremtésében (Van Der Sluis, 2004). Burns és Stalker (1969) mechanikus és az organikus stuktúrát különböztetett meg egymástól. Empirikus kutatásaik alapján az előbbi stabil környezetben, az utóbbi pedig változó környezetben bizonyult jobb megoldásnak. A szervezeti strukturának többféle tipologizálása létezik, a kutatók viszont máig hivatkozzák Burn és Stalker munkáját és ezt a kettő, egymás ellentétét képező típust mutatják be ideális típusként stabil vagy változó környezetben (Horváth és Szabó, 2017; Green, 2019; Daft, 2012; Shamim et al., 2016). Jellemzőiket az 1. táblázatban foglaltam össze. 
International Journal of Engineering and Management Sciences (IJEMS) Vol. 5. (2020). No. 1

DOI: $10.21791 /$ IJEMS.2020.1.41

\begin{tabular}{|l|l|l|}
\hline & Mechanikus szervezet & Organikus szervezet \\
\hline Múködése & mint egy gép & mint egy élőlény \\
\hline Szabályok & részletes, szigorú & kevés, nem veszik figyelembe \\
\hline Vezetői/végrehajtói feladatok & élesen el vannak választva & összekeverednek \\
\hline Rangok, beosztások & hangsúlyos szerepben & nincs különösebb jelentőségük \\
\hline Kommunikációs csatornák & fontos az írásbeliség & nyitottak, személyesek \\
\hline
\end{tabular}

1. táblázat. Mechanikus és organikus stuktúra

(Forrás: Saját szerkesztés, Horváth és Szabó, 2017; Green, 2019; Daft, 2012; Shamim et al., 2016 munkái alapján)

A szervezet belső irányítási struktúrája összefügg azzal, hogy éppen milyen a külső környezet. Dajnoki és Héder (2017) arról írnak, hogy a szervezetek számára mindig is komoly kihívást jelentett a változó környezethez való gyors és rugalmas alkalmazkodás.

Amennyiben a külső környezet stabil, úgy a belső struktúra esetében ideális, ha a szervezet úgy működik, mint egy gép. Egységes szabályok, eljárások jellemzik, a vezetői és végrehajtói feladatok élesen elkülönülnek egymástól és egyértelmű hierarchia jellemezi, ahol az írásbeliség fontos szerepet kap. Ezt a struktúrát nevezte Burns és Stalker (1969) mechanikusnak.

Ezzel szemben a gyorsan változó környezetben a belső szervezet sokkal lazább kell, hogy legyen. Működése egy élőlényhez hasonló, kevés szabály jellemzi, amelyeket gyakran írásba sem foglalnak. A dolgozóknak saját maguknak kell kitalálni, hogy mit és hogyan kell tenni. Előfordul, hogy egy ember az egyik projektben vezetőként, a másikban beosztottként van jelen, azaz a hatalom hierarchiája nem egyértelmű, a rangoknak és beosztásoknak nincs különösebb szerepe, vagyis a struktúra organikus (Daft, 2012).

\subsection{Vezetési stílus}

Dobák (2008) szerint a vezetésnek az egyik fontos feladata, hogy a környezet kihívásaihoz alkalmazkodva szervezeti változásokat hajtson végre az optimális teljesítmény elérése érdekében. Pierog és Szabados (2015) azt hangsúlyozzák, hogy egy szervezetben az elvégzendő feladatok határozzák meg azt, hogy a vezetőknek milyen speciális ismeretekkel kell rendelkezniük. Yukl (2010) véleménye alapján hatékony munka szükséges ahhoz, hogy a vezető megfelelő támogatást nyújtson ennek a változásnak a megvalósításában. Több kutató (Dajnoki, 2015; Arslan and Staub, 2013; Auken et al., 2008; Avolio and Bass, 1991) véleménye alapján a vezető stílusa fontos szerepet játszik a szervezet változásokhoz való alkalmazkodásában, hatékonyságában. A vezetés teljes kiterjedése modellt Avolio és Bass (1991) fejlesztette ki. A modell a vezetési stílusok teljes skáláját írja le a nem-vezetéstől a tranzakciós vezetésen át a transzformációs vezetésig (1. ábra). 


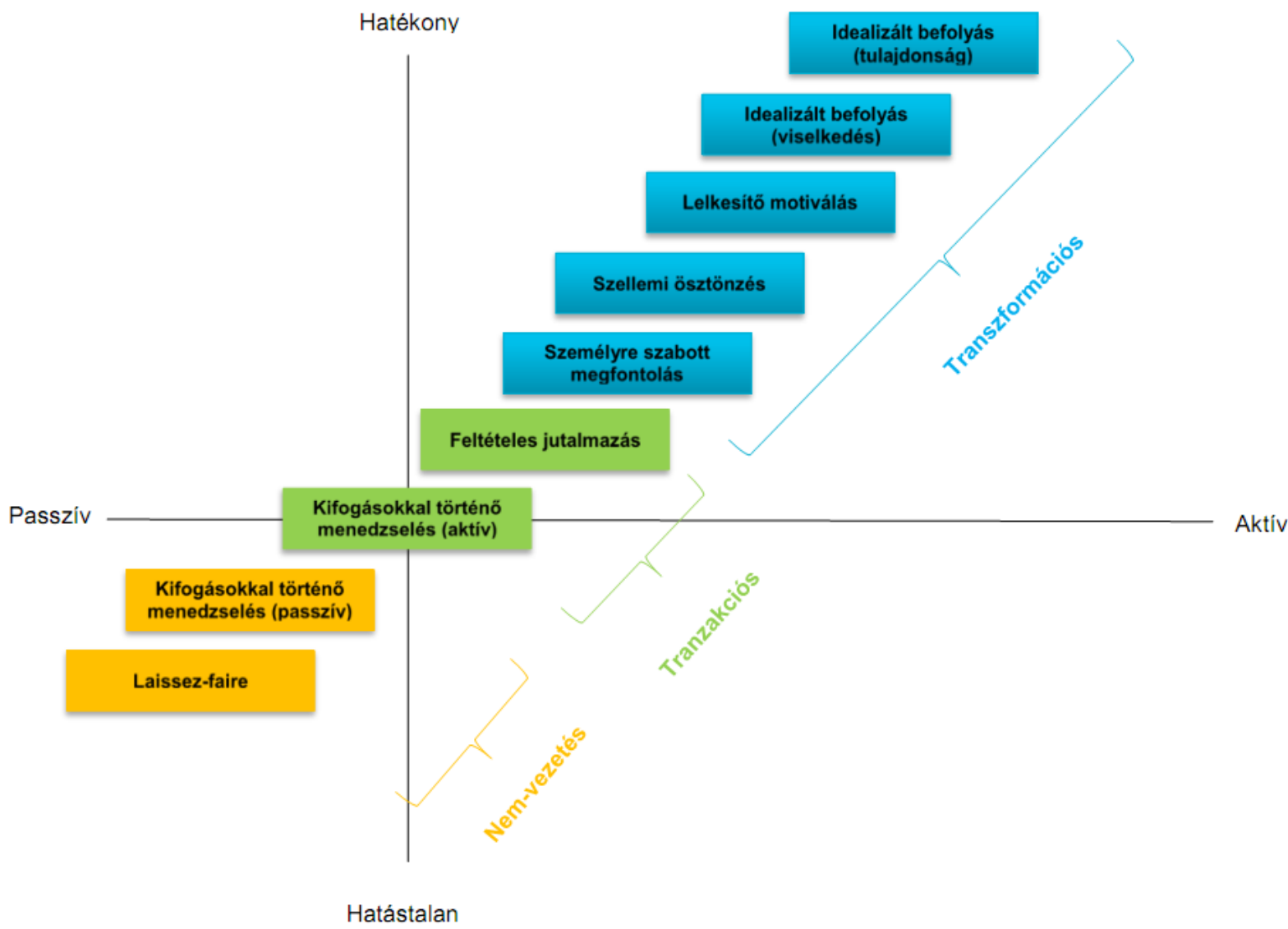

1. ábra. Vezetés teljes kiterjedése modell

(Forrás: Filep, 2018)

Az alábbiakban Avolio and Bass (1991) munkája alapján foglalom össze a nem-vezetés, tranzakciós és transzformációs vezetési stílusokat. Kutatásaik szerint a nem-vezetés a leginkább passzív és hatástalan stílusnak tekinthető, amely a laissez-faire és a kifogásokkal történő menedzselés (passzív) stílusokat foglalja magában. Előbbi esetében a vezető érzéketlen a követők szükségleteire és csak minimális támogatást nyújt. Utóbbi stílusnál csak rendkívüli helyzet esetén tesz intézkedéseket, reaktív magatartást követ.

A tranzakciós vezetés a "valamit valamiért" elvet követi, a kifogásokkal történő menedzselés (aktív) esetén precíz ellenőrző rendszert alakít ki, amely gyors visszajelzést biztosít a beosztottak részére, viszont korlátozza az innovációt. Feltételes jutalmazás estén a megfogalmazott célok teljesítésével anyagi és nem anyagi jutalmakat biztosít, ennek a helyes alkalmazása esetén eléri a kívánt teljesítményt.

A transzformációs vezetés az érdekekről az értékekre váltást tükrözi, a legaktívabb és leghatékonyabb stílusokat foglalja magában. Az alábbi öt stílus tartozik ebbe a kategóriába.

1. Személyre szabott megfontolás estén a vezető figyelembe veszi a beosztottak képességeit és igényeit, akik testreszabott feladatokat kapnak.

2. Szellemi ösztönzésnél a vezető ösztönzi a régi módszerek újragondolását, az innovációt, a problémák új megoldásokkal történő kísérletezésére bátorítja a dolgozókat. 
3. Lelkesítő motiválás estén ellenállhatatlan stílusban igyekeznek megfogalmazni a víziójukat, amellyel a követők megnyerésére törekszenek.

4. Idealizált befolyásnál (viselkedés) bizalmi kapcsolat kiépítésére törekszenek, ahol kulcsszerepet kap a kívánatos jövőkép, valamint a legfontosabb értékek és hiedelmek.

5. Idealizált befolyás (tulajdonság) a bizalmi kapcsolat kiépítésének az alapját a vezető karizmatikussága, erkölcsi tartása jelenti, akik önmaguk érdekei helyett a csoporttagokéra helyezik a fókuszt.

\subsection{HR gyakorlatok}

HR tekintetében a felvétel, a tréningek, munkatervezés, kompenzáció, teljesítményértékelés a leginkább hangsúlyos területek (Horváth és Szabó, 2017; Shamim et al., 2016; Van Der Sluis, 2004).

\begin{tabular}{|l|l|}
\hline & Szükséges jellemzők \\
\hline Felvétel & innovatív tulajdonságok \\
\hline Tréningek & problémamegoldó készség fejlesztése \\
\hline Munkatervezés & rugalmasság \\
\hline Kompenzáció & teljesítmény alapú \\
\hline Teljesítményértékelés & fontos az írásbeliség \\
\hline
\end{tabular}

2. táblázat. HR változásmenedzsment szempontból hangúlyos területei

(Forrás: Saját szerkesztés Horváth and Szabó, 2017; Shamim et al., 2016; Van Der Sluis, 2004 munkái alapján)

Napjaink szervezeteinek egyik legnagyobb versenyelőnyét a dolgozók szaktudása jelenti (Barizsné Hadházi, 2004). Barrick és Mount (1991) szerint már a felvételkor ügyelni kell arra, hogy olyan dolgozók kerüljenek kiválasztásra, akik innovatív tulajdonságokkal rendelkeznek. Legyenek nyitottak az új ismeretekre, kellő kreativitással és képzelőerővel rendelkezzenek. Az új belépők és a meglévő dolgozók tréningelése esetén a kutatók a csapatépítés és a csapatmunka fontosságára hívják fel a figyelmet. Lényeges a problémamegoldó készségek fejlesztése is, amely változó környezetben kulcsfontosságú lehet, hiszen jól strukturált problémák mellett, különösen turbulens környezetben számos rosszul strukturált probléma merülhet fel, amelyek esetén újszerű gondolkodásra lehet szükség. A munkatervezésnek a csapatmunka megkönnyítését kell szolgálnia, tehát kulcskérdés, hogy a feladatok megtervezése rugalmas legyen.

Prieto és Pérez-Santana (2014) írása alapján a kompenzációnál ügyelni kell arra, hogy teljesítmény alapú legyen. Ehhez kapcsolódik a teljesítményértékelés, amelynek teljesítmény és viselkedés alapúnak kell lennie ahhoz, hogy a tanulást és az innovációt támogatni tudja. A folyamatos visszajelzés legalább annyira fontos tényezőként jelenik meg, mint az objektivitás. 


\section{Eredmények}

Struktúra vonatkozásában a kutatók (Horváth és Szabó, 2017; Green, 2019; Daft, 2012; Shamim et al., 2016) nem tesznek javaslatot egyetlen feltétlenül alkalmazandóra, viszont hangsúlyozzák, hogy instabil, változó környezetben, amely az ipar 4.0-t is jellemzi, olyan struktúrát érdemes kialakítani, amelyet decentralizáció, kevés szabály, horizontális kommunikáció és együttműködő csapatmunka jellemez, azaz sokkal inkább organikus, mint mechanikus.

Vezetési stílus tekintetében a transzformációs vezetés kerül említésre a leggyakrabban, viszont az ipar 4.0 esetében ennél is többre van szükség, mert különböző korlátai lehetnek. A szakirodalom az ipar 4.0 előtt is kiemelte, hogy a transzformációs és a tranzakciós vezetés megfelelő kombinációjaként határozható meg az ajánlott vezetési stílus, az utóbbi évek ipar 4.0val kapcsolatos kutatásai is azt hangsúlyozzák, hogy a kettő elegyeként előálló tudás orientált vezetési stílus kibővített konstrukciója könnyítheti meg leginkább az innovációt és a tanulást. Avolio és Bass (1991) hangsúlyozza, hogy a transzformációs vezetés nagy mértékben növeli a tranzakciós vezetői viselkedés hatékonyságát.

A vezetők különféle HR gyakorlatokkal alakíthatják a dolgozók készségeit, javíthatják tanulási képességeiket, a rugalmasság, a problémamegoldó készségek fejlesztése és a teljesítmény alapú kompenzáció kerülnek fókuszba. A felvétel, a tréningek, munkatervezés, kompenzáció, teljesítményértékelés a leginkább hangsúlyos területek (Horváth és Szabó, 2017; Shamim et al., 2016; Van Der Sluis, 2004).

\section{Következtetések}

A megfelelő struktúra, a vezetési stílus és a HR tehát felkészítik a szervezetet a változásokra és az ipar 4.0-ra azáltal, hogy megkönnyítik a tanulást, javítják a képességeket és támogatják az innovációt.

A három áttekintett területet (struktúra, stílus, HR) vizsgálva többféle összefüggés is feltárható. A „valamit valamiért” elvet a HR gyakorlatokon belül a kompenzáció és a teljesítményértékelés esetén, vezetési stílusnál pedig a tranzakciós vezetésnél is megfigyelhetjük. A „rugalmasság” a transzformációs vezetésnél a követőkre bízott, személyre szabott feladatoknál jelenik meg, amely az organikus struktúránál is kulcsfontosságú szerepet játszik, a HR gyakorlatokon belül pedig a munkatervezésnél mutatkozik meg.

További kutatás keretében érdemes lehet különböző méretű szervezetek körében, empirikus vizsgálatok elvégzésével tesztelni a szakirodalmi megállapításokat. A vezetési stílus alakítható és a dolgozói készségek fejleszthetők (Dvir et al., 2002; Barrick és Mount, 1991), azt is érdemes lehet részletesen megvizsgálni, hogy pontosan milyen módon, milyen csapatépítő és problémamegoldó tréningekkel fejleszthetők a különböző készségek.

„Az Innovációs és Technológiai Minisztérium ÚNKP-19-3 kódszámú Új Nemzeti Kiválóság Programjának szakmai támogatásával készült."

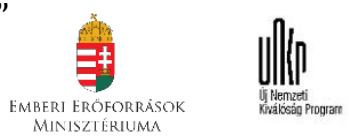




\section{Hivatkozások}

[1] A. Arslan és S. Staub (2013) 'Theory X and Theory Y Type Leadership Behavior and its Impact on Organizational Performance: Small Business Owners in the Şishane Lighting and Chandelier District', Procedia - Social and Behavioral Sciences. Elsevier, 75, pp. 102111.

[2] H. Auken Van et al. (2008) 'Innovation and SME Performance in Spanish Manufacturing Firms Value, fair value and ethic View project Financiación a la PYME mexicana View project Innovation and performance in Spanish manufacturing SMEs', Article in International Journal of Entrepreneurship and Innovation Management, 8(1), pp. 36-56.

[3] B. J. Avolio és B. M. Bass (1991) The full range of leadership development: Basic and advanced manuals. NY: Bass,. Binghamton.

[4] E. Barizsné Hadházi (2004) ‘44 hazai vállalat oktatáspolitikája’. Budapesti Corvinus Egyetem Gazdálkodástudományi Kar Budapesti Vezetőképző Központ.

[5] M.R. Barrick és M. K. Mount (1991) 'The Big Five Personality Dimensions and Job Performance: A Meta-Analyis', Personnel Psychology, 44(1), pp. 1-26.

[6] T. Burns és G. Stalker (1969) 'The Management of Innovation', The Economic Journal, 79(314), pp. 403-405.

[7] R. L. Daft (2012) Organization Design and Theory. South-Western College.

[8] K. Dajnoki (2015) ‘A vezetési stílus, mint a hatékony vezetés alapjai In: Bácsné B. É., Berde Cs., Dajnoki K.: A vezetés alapjai', Debreceni Egyetem, ISBN: 9786, pp. 83-96.

[9] K. Dajnoki és M. Héder (2017) '„Új szelek fújnak” - a HR válasza a globalizáció és a változás kihívásaira', Hadtudomány: A magyar hatdutományi Társaság folyóirata, pp. 84-93.

[10] M. Dobák (2008) Szervezeti formák és vezetés, Akadémia Kiadó.

[11] T. Dvir et al. (2002) 'Impact of Transformational Leadership on Follower Development and Performance: A Field Experiment', Academy of Management Journal. Academy of Management, 45(4), pp. 735-744.

[12] R. Filep (2018) 'Vezetési stílus vizsgálata MLQ segítségével a szabolcs-szatmár-bereg megyei kisvállalkozások körében', International Journal of Engineering and Management Sciences (IJEMS), 3(4).

[13] M. Green (2019) Management scholarship and organisational change : representing Burns and Stalker.

[14] D. Horváth és Z. R. Szabó (2017) A negyedik ipari forradalom vezetési aspektusai Corvinus Kutatások, In: Mérleg és Kihívások X. Nemzetközi Tudományos Konferencia = „Balance and Challenges” X. International Scientific Conference. Miskolci Egyetem Gazdaságtudományi Kar, Miskolc-Egyetemváros.

[15] A. Pierog és Gy. Szabados (2015) 'Civil szervezetek vezetési szempontból', 
International Journal of Engineering and Management Sciences (IJEMS) Vol. 5. (2020). No. 1 DOI: 10.21791/IJEMS.2020.1.41

Vezetéstudomány - Budapest Management Review, 46(2), pp. 35-46.

[16] I. M. Prieto és M. P. Pérez-Santana (2014) 'Managing innovative work behavior: The role of human resource practices', Personnel Review. Emerald Group Publishing Ltd., 43(2), pp. 184-208.

[17] M. Sebők (2017) ‘Munkaerőhiány és a munkaerő-mobilitás empirikus kutatása', Tudás Menedzsment, A Pécsi Tudományegyetem Kultúratudományi, Pedagógusképző és Vidékfejlesztési Kar periodikáj, XVIII. évf, pp. 55-64.

[18] S. Shamim et al. (2016) 'Management Approaches for Industry 4.0', Evolutionary Computation (CEC), 2016 IEEE Congress, pp. 5309-5316.

[19] L. E. Van Der Sluis (2004) 'Designing the workplace for learning and innovation : Organizational factors affecting learning and innovation', Development and Learning in Organizations: An International Journal, 18(5), pp. 10-13.

[20] G. A. Yukl (2010) Leadership in organizations. Prentice Hall. 